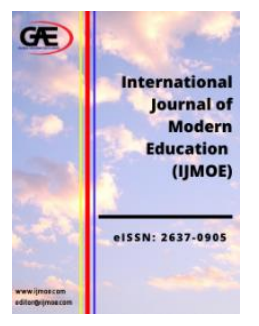

\author{
International Journal of Modern Education \\ (IJMOE) \\ Journal Website: http://ijmoe.com/ \\ eISSN: 2637-0905
}

\title{
LANGUAGE LEARNING AND TEACHING USING KAHOOT!
}

\author{
Paramjit Kaur ${ }^{1 *}$, Reenuga Nadarajan ${ }^{2}$ \\ 1 School of Education and Modern Languages, Universiti Utara Malaysia, Malaysia \\ Email: paramjit@uum.edu.my \\ 2 GEMS International School Pearl City, Penang, Malaysia \\ Email: nreenu1789@gmail.com \\ * Corresponding Author
}

Article Info:
Article history:
Received date: 13.01 .2020
Revised date: 12.06 .2020
Accepted date: 14.06 .2020
Published date: 15.06 .2020
To cite this document:
Kaur, P., \& Nadarajan, R. (2020).
Language Learning And Teaching
Using Kahoot!. International Journal
of Modern Education, 2(5), 19-28.

DOI: $10.35631 /$ IJMOE.25003

\begin{abstract}
:
There are various technological tools and software that can be used to enhance the language teaching-learning process. Research has shown that the integration of 'gamification' based software like Kahoot! has the ability to influence and enhance language learning outcomes and can be used as effective teaching and assessment tools in language classrooms. This study explores the language teaching and learning experiences of five teachers and 50 secondary students in an international school when they used Kahoot! in their English classes. The study employed a questionnaire with ten items using a five-level categorical Likert scale and a semi-structured interview to collect data. Almost all the teachers reported that Kahoot! was an effective teaching and assessment tool, and the use Kahoot! enabled the teachers to engage students actively in classes. The results from the questionnaire highlighted that almost all the students reported positive experiences when they had lessons integrated with the use of Kahoot!. The majority of students reported that they were able to engage actively in their language lessons when Kahoot! was used. Almost all the students reported positive experiences when they used Kahoot! in their language classrooms. Generally, it was found that Kahoot! enabled students to engage and actively participate in their language learning processes, and teachers used Kahoot! to create a more meaningful and rich language learning experience for their students.
\end{abstract}

\section{Keywords:}

English Language Learning and Teaching, Kahoot!, Gamification, ICT in Language Teaching and Learning, Malaysia

\section{Introduction}

Research shows that technological hardware and software such as computers, tablets, online teaching and learning applications have the ability to enhance students' engagement and 
active participation in the classrooms in an effective manner as well as help teachers teach in a more meaningful and effective manner (Bransford, Brown \& Cocking, 2007; Cox \& Rogers, 2005; Chun, Kern \& Smith, 2016; Kim \& Reeves, 2007; Koile \& Singer, 2006). Technology increasingly occupies most aspects of our lives. Thus education contexts need to change and adapt according to the current needs learners and their learning strategies and preferences. Education too needs to prepare citizens for the workplace that is becoming increasingly dependent on technology. Therefore, teachers and educators should try to complement traditional textbooks with learning software in order to enhance students' engagement in learning and prepare students for the job market.

Malaysia requires a workforce that need to function and compete in a globally and technological enhanced world. Thus, the Ministry Education of Malaysia has outlined a set of additional skills and competencies that are aligned with the National Education Philosophy, which will provide students a competitive edge at an international level. According to the Malaysian Educational Blueprint 2013-2025, there are several strategies to ensure that students are prepared with the required skills to face global challenges and to transform students through the application of Science, Technology, Engineering and Mathematics (STEM) in relevant subjects. Several strategies and curriculum enhancements have been introduced to increase the development of students' skills and competencies. These strategies include new innovative learning approaches and an enhanced curriculum that emphasises high order thinking skills.

Various learning software and platforms have been specifically developed to assist English language teachers in their classrooms (Chun, Kern \& Smith, 2016). These software and platforms are also developed to enhance and optimise students' language learning experiences. Adaptive learning software such as Kahoot! that are based on gamification elements enrich classroom activities as this software can engage students, supply feedback and structure participation courses. Various researches and studies that involve educational settings have proven that the infusion of 'gamification' in the teaching and learning process has the ability to influence learning experiences as well as students' behaviour and language learning outcomes (Deterding, Dixon, Khaled, \& Nacke, 2011). Studies should examine how students' experiences with such gamification based activities can lead to higher engagement in their language learning processes as well as how teachers integrate these activities into their classroom teaching. This exploratory paper examines the perspectives of English language teachers and students about the use of Kahoot! in language classrooms in an international school located in northern Malaysia. Specifically, this study examines the effectiveness of the Kahoot! platform from students' and teachers' point of views in terms of language learning and teaching experiences.

\section{Literature Review}

There three sub-sections in the literature review. These include technology in the language classroom, gamification in language learning and teaching, and Kahoot! in the language classroom.

\section{Technology in the Language Classroom}

The education system experiences transformation constantly. These transformations lead to a high level of complexity in terms of the challenges that arise and place new demands on learners and teachers. There is a constant need for change and improvement in teaching and learning methods. For learners today, technology has become part of their culture and lives as the current generation are known as digital natives. "A digital native is someone who was 
raised in a digital, media-saturated world" (Meyer, 2010). Therefore, in order for classrooms and schools to be relevant to these digital natives, teaching and learning need to cater for the digital lifestyle of today's generation, and new technologies need to be integrated in classrooms. Increasingly, various adaptive learning software and technological tools have replaced traditional classroom methods that are based on textbooks and blackboards as learning and teaching tools.

The integration of technology into learning and teaching has been an effective measure to connect with student's learning style. All students learn differently, and technology allows educators to accommodate the unique learning styles of different students (Bernard, Chang, Popescu \& Graf, 2017). Allowing students' to use technology through their devices such as tablets and smartphones in their learning activities will encourage them to actively participate in classrooms. In addition, the use of technology by teachers can also transform traditional passive learning models to more active modes as teachers take on roles as motivators, advisors and coaches. Teachers will be able to have better interaction with students as they assist students through the use of technological tools and obtain responses and feedback from students throughout the learning process. Teaching and learning become more dynamic and students gain skills that will help them be more viable for the workforce later on.

\section{Gamification in Language Teaching and Learning}

Gamification based educational software use game-based activities and video games to engage its audience in educational contexts (Icard, 2014). Gamification has been used in various fields such as marketing, finance, and health; and recent times has been used as a new type of strategy for language learning and instruction (Deterding et al, 2011). Deterding et al (2011, p. 9) also states that the main objective of integrating gamification based classroom activities is to "motivate and increase user activity and retention" via a "rewards and reputation system". The creation of interactive games for teaching and learning in classrooms promotes independent and collaborative learning as well as enhances critical thinking and problem solving skills (Icard, 2014). Teachers can adapt the interactive games to suit their lesson outcomes as well assessment criteria. Progress indicators in a game also make learning and self-evaluation more visible and interactive. Using gamification based tools and software also helps students adapt and enhance their technological skills that are a requirement of the 21st century. Teachers can also develop materials that will enhance their own teaching experiences and encourage a classroom environment that is more collaborative and stimulating. Theoretically, fun and enjoyable gaming environment increases responses and participation among students' in the learning process thus generating positive learning outcomes (Dellos, 2015).

According to Livingstone (2015), gamification based teaching and learning activities allow learners to be engaged in meaningful communication and take on active roles in their own learning. Activities that are based on games stimulate learners and motivate them to learn on their own. These activities also lessen students' anxiety towards learning English and create a positive environment for English language learning. Students need to follow instructions while playing games in order to get the feedback and at the same time they are exposed to the target language (Piskorz, 2017). Language teachers often face problems to create lessons that can sustain their students' interests and attention in class. Thus, gamification based activities in English classrooms can offer teachers a more fulfilling and engaging classroom environment as these activities are relatively easy to design and provide learners with language practice and can also be used as an assessment tool that provides immediate feedback to students. Teachers can also design lessons that are tailored to suit learners' 
individual differences. Gamification based activities and tools offer more effective language learning and teaching environment for learners and teachers.

\section{Kahoot! in the Language Classroom}

Kahoot! is a platform that comprises quizzes, discussions and surveys and is based on gamification mechanics. Kahoot! has its own unique features that are typical of gaming and teaching models. Kahoot! is a game-based platform for students to engage in learning in a fun and competitive manner. Instead of the traditional method of textbooks and notes, Kahoot! encourages users to learn, collaborate and socialize in virtual classrooms thus creating an active learning environment (Graham, 2015). Kahoot! is a game-based response system which is played by the whole class in real-time or 'live' time. An example of a Kahoot! application is during a lesson, questions can be projected on the screen and students would have to answer the questions via devices such as a tablet, smartphone or computer.

Many education institutions have begun to invest in adopting technological tools and software such as Kahoot! in classroom activities as an effort to restructure teaching approaches with current technological advancements (Zhao, Sheldon \& Byers, 2002). Research has shown that students' are more engaged and have higher collaboration when Kahoot! is used in their classrooms (Icard, 2014). Students enjoy participating using Kahoot! in language-based activities as the content is appealing and fun. Students also can compete with their peers in real time and this gives them a sense of competition. The features of Kahoot! also enable teachers to analyze and assess if students truly understand the learning material covered through the use of Kahoot! quizzes and surveys.

Integrating technology in classroom assessment enables the teacher to facilitate and monitor the lesson without interrupting students' participation (Moersch, 1998). Thus, language learning experiences in the classroom becomes more dynamic, open-ended and multidimensional. In many education settings, the application of technology is slowly becoming a common practice in giving feedback and assessing students' learning (Nicol \& Milligan, 2006; Saade, 2003). Kahoot! based activities offer a method of giving feedback almost instantly without interrupting students' engagement in the activity. Kahoot! also allows students to create their own surveys and quizzes to show understanding of the subject matter (Medvedovska, Skarlupina \& Turchina, 2016).

Kahoot! can enhance students' engagement in activities while still physically remaining in a typical traditional class. There is no necessity for access to computer labs to engage in Kahoot! based activities as students can use their own devices such as phones and laptops. Traditional activities such quiz, discussion and surveys can be conducted on the Kahoot! platform but in a more fun and interactive way. Bitner \& Bitner (2002) state that teachers are able to use Kahoot! to manage lessons and assessments. The integration of Kahoot! in classroom activities creates a fun and interactive atmosphere in the classroom (Lee \& Hammer, 2011). Overall, Kahoot! is a great gaming response system that has a variety of uses for teachers in the classroom because it is user friendly and open ended. Kahoot! offers students a learning tool that is interactive, fun and offers immediate feedback. The gamebased feature of Kahoot! is attractive for students and especially useful for language learning activities as it allows students to freely practice their language skills with their peers in real time as well as get actual reactions. 


\section{Methodology}

This paper examines teachers' and students' perspectives and experiences of using the Kahoot! platform in their English language teaching and learning. This exploratory study was conducted in an international school situated in the northern Malaysia. There are 51 academic staff in the school and a total of 412 students, Malaysians and foreigners. The international school offers the British International curriculum at early years, primary, secondary and pre-university levels. The students need to sit for an English exam to be placed in their respective classes.

The participants of this study comprised of 50 secondary level students with a mix of Year 9, Year 10 and Year 11 students; as well as five full time teachers. 33 students were Malaysians and 17 were non-Malaysians. 29 of the students were learning English as second language while 22 were learning English as a first language. Three of the teachers were teaching at secondary level and two at primary. Two of the participants (referred to as Teacher A and Teacher B) in this study are British while the other three participants (Teacher C, Teacher D and Teacher E) are Malaysians. The teachers had language teaching experience ranging from five to fifteen years. All of them are university graduates with Bachelor Degrees in English language.

A self-developed questionnaire consisting of ten questions was used to collect data from the 50 students. The aim of the questionnaire was to gather students' perspectives and experiences of the use of Kahoot! in their lessons. The questionnaire was administered with during school hours. There are two sections in the questionnaire. Section A consists of four items about participant's demographic information. Section B consists of ten items with a five-point Likert scale. The items are all related to the students' perceptions and feelings about the use of Kahoot! in their English language classrooms. All the items were in English as the students were taken to be proficient in the language.

Data from teachers was collected via semi-structured interviews. Teachers were asked about their experiences and thoughts about the use of Kahoot! in their classrooms. The interview consisted of 13 open-ended interview questions. The interview questions were developed by researchers based on literature review. The responses from the five teachers were transcribed and analyses. Five themes were discovered from the interviews.

\section{Findings and Discussion}

This section presents the findings and discussion in two sections; namely teachers' and learners' perspectives.

\section{Teachers' Perspectives on the Use of Kahoot!}

The analysis of the transcribed interviews of the five teachers elicited six themes regarding teachers' perspectives on the use of Kahoot! in their language teaching. These themes included 'familiarity with Kahoot!', 'Kahoot! as teaching tool', 'Kahoot! for language learning', 'Kahoot! and assessment', 'suitability of Kahoot! as classroom activity', and 'student engagement'. All the teachers voiced that they regularly used Kahoot! based activities in their classroom and it was an effective teaching tool as students were highly engaged when Kahoot! based activities were carried out. As Teacher A points out about the effectiveness of Kahoot, "Yes, in my opinion it is. It positively influences students. As a whole I believe Kahoot! is very helpful in teaching and should be used more in classes and it brings positivity to students. It also helps me to measure students understanding of a topic at the end of each lesson". 
Four out of the five teachers are highly experienced users of Kahoot!. Only, one teacher (Teacher C) had to develop her knowledge and skills of Kahoot! as a result of the school policy of integrating Kahoot! Teacher A (a highly experienced user of Kahoot!) describes "Kahoot! is a two-way technology system to assist in conducting classroom activities such as quizzes, discussions and surveys. Questions will be posted on the screen and students can use their smart gadgets either mobile phones, iPads, or computers and answer the questions". However, Teacher C (initial novice of Kahoot!), expressed that she did not have initial knowledge or skills about Kahoot! but attempted to learn and use it as it was highly popular among students and other teachers. Teacher $\mathrm{C}$ reported that "I had no idea what Kahoot! is until I joined this school and realize most teachers utilize this application in classroom teaching. I gradually learned about Kahoot! and applied it in my teaching process. I also learnt about challenging people and also sharing, duplicate the Kahoot! game which already exist in the online Kahoot! application."

All the teachers expressed that their students were highly engaged during lessons that integrated Kahoot!. These teachers remarked that students were highly enthusiastic and collaborated actively to complete tasks. For example, Teacher A remarked about her students during Kahoot! activities as "They love it. There is a positive active participation. I frequently hear this from my students; 'it's 'competitive, I like winning games', 'it's nice to use mobile phones in classroom with teacher's permission', 'the background music makes me to think well', 'it's a warm up especially in mornings"'. Overall all the teachers interviewed in this study agreed that Kahoot! based activities that were integrated into their classrooms were highly beneficial for their students. Teachers are continuously upgrading and adapting to the latest teaching method in order to keep up with the latest technological changes as well as to engage with their students who are more technologically inclined (Livingstone, 2015).

\section{Students' Perspectives on the Use of Kahoot!}

The results from the questionnaire that was distributed to 50 respondents were tabulated based on percentages. Table 1 shows the findings of the study from the questionnaire for the ten items in the questionnaire.

Table 1: Students' Perspectives on Kahoot! in English Classes

\begin{tabular}{|c|c|c|c|c|c|c|}
\hline No & Item & $\begin{array}{l}\text { Strongly } \\
\text { Agree }\end{array}$ & Agree & Neutral & Disagree & $\begin{array}{l}\text { Strongly } \\
\text { Disagree }\end{array}$ \\
\hline 1 & $\begin{array}{l}\text { Kahoot! is a fun way of learning } \\
\text { language subjects. }\end{array}$ & $62 \%$ & $38 \%$ & - & - & - \\
\hline 2 & $\begin{array}{l}\text { I feel positive towards my learning when } \\
\text { I participate in Kahoot! games. }\end{array}$ & $36 \%$ & $58 \%$ & $6 \%$ & - & - \\
\hline 3 & $\begin{array}{l}\text { I found that Kahoot! application } \\
\text { stimulates learning. }\end{array}$ & $46 \%$ & $54 \%$ & - & - & - \\
\hline 4 & $\begin{array}{l}\text { Kahoot! is an innovative tool designed } \\
\text { to engage me with learning. }\end{array}$ & $32 \%$ & $66 \%$ & $2 \%$ & - & - \\
\hline 5 & $\begin{array}{l}\text { I feel motivated when I compete with } \\
\text { my friends to get higher scores in } \\
\text { Kahoot! game. }\end{array}$ & $60 \%$ & $38 \%$ & $2 \%$ & - & - \\
\hline 6 & $\begin{array}{l}\text { The question sets available in the } \\
\text { Kahoot! application are related to my } \\
\text { lessons. }\end{array}$ & $30 \%$ & $64 \%$ & $6 \%$ & - & - \\
\hline
\end{tabular}


7 Kahoot! team mode enables me to discuss and collaborate with my teammates.

8 I learn language lessons better when I can create question and answer sets and also provide illustrations on the Kahoot! template.

9 Language question sets available in Kahoot! help me to improve my language learning in interesting way.

10 I prefer my teacher to conduct Kahoot! activity at least twice a week.

Based on Table 1, participants mostly chose between 'strongly agree' and 'agree' for almost all the items. Items 1, 2 and 3 are concerned with Kahoot! being a useful resource for learning. Almost all respondents strongly agreed with items 1, 2 and 3 which measured Kahoot! as a useful resource for learning. Items 4 and 5 which are related to the features of Kahoot! as being an innovative tool and provides a sense of competition as students complete activities in real time and their scores can be seen by their peers. Results showed that for items 4 and 5, respondents also strongly agreed to both items. Most students agreed that the features of Kahoot! were useful to them and provided them with ample learning opportunities.

For item 8 , the responses show that majority of the respondents agreed with the statement that creating question and answer sets together with illustrations on the Kahoot! template enabled them to learn better. However, a small number $(8 \%)$ chose to stay 'neutral' with the statement. Majority of the respondents strongly agreed with item 9 that states that Kahoot! is helpful in improving their language learning in an interesting way. However, item 9 is the only item that had the highest number of 'neutral' responses among all the 10 items. Some of these students may feel that Kahoot! is not a learning activity as it is gamer based, although teachers may have integrated learning objectives. For item 10, almost all the respondents were positive towards the statement that Kahoot! should be conducted at least twice a week.

The findings from questionnaires revealed that that almost all the respondents have positive experiences and feelings about the application of Kahoot! in their language learning. None of the students strongly disagreed with any of the ten items. Only item 7 "Kahoot! team mode enables me to discuss and collaborate with my teammates" showed a 'disagree' reaction by $6 \%$ of the students. Some of the students may have introvert personalities who prefer to learn on their own (Bitner \& Bitner, 2002). Activities based on Kahoot! mainly need students to collaborate in order to complete activities, and therefore may be unsuitable for students who prefer to work alone. For most of the items, majority of the students either agreed or strongly agreed with the statements. This is indicated that these students had positive perceptions about the use and the features of Kahoot! in their own language classes. Even the teachers who were interviewed, largely expressed positive reactions and experiences about the use of Kahoot! in their teaching. These teachers also expressed that their students seemed to enjoy and benefitted from the use of Kahoot! based activities.

The findings in this study are similar to the findings of the study done by Bicen (2018) where it was found that students, who were preservice teachers reported positive reactions on the use of Kahoot! in their classes. Bicen (2018) reported that the preservice teachers reported 
Kahoot! had a positive impact especially the features of instant feedback as well as the engaging activities in Kahoot! made learning seem fun. Yapici \& Karakoyum (2017) also found that their respondents who were preservice teachers had positive experiences with Kahoot! where these future teachers indicated that they would adopt the use of Kahoot! in their own classes when they start teaching. These preservice teachers reported that Kahoot! made their learning engaging and enhanced their learning experiences (Yapici \& Karakoyum, 2017).

One factor that needs to be highlighted in this study is the context and sample of the study. As the context of this study is an international school with students who are mostly proficient in the English language, this could have influenced the findings and limited the study. An international school has its own unique features that consist of multinational students, global curriculum and ample infrastructure that may allow teachers and students to fully use Kahoot!. Teachers in this school are also encouraged to use Kahoot!. Those who have no knowledge about Kahoot! are given training to integrate Kahoot! in their classroom activities. Infrastructure to support the use of technology in teaching and learning is also constantly upgraded to meet with current changes and advances. Thus, the school provides a platform and instills an awareness of the importance of technology and its benefits in education. According to King (2017), information and communication technology improves the quality of education. Teachers need to be given training to fully utilise technology to enhance their teaching and enhance students' learning experiences. Students are digital natives and only focusing on traditional methods and materials may not be enough to engage these students in classrooms. Although, the context may limit the generalisation of the findings, this study shows that given the proper infrastructure and training game-based applications such as Kahoot! can benefit teachers and learners.

\section{Conclusion}

Kahoot! based activities in English language classrooms can help to instil positive attitudes, increase motivation of students, create fun and enjoyable learning environment (Medina \& Hurtado, 2017). For teachers, Kahoot! offers an alternative assessment method and helps create meaningful activities that can promote student engagement. Thus, teachers need to have access to technology within their classrooms and feel comfortable utilizing that technology in their instruction. Kilickaya \& Krajka (2010) found that although technology appears to make instruction meaningful to students, teachers are unsure how to incorporate technology into their instruction. Teachers should receive professional development to incorporate game-based learning platforms into their daily instruction to help students remain engaged, motivated, and to promote retention (King, 2017).

From this small exploratory study, it can be seen that Kahoot! can provide positive learning experiences to students in their language classroom. Students involved in this study expressed positive experiences and outcomes in their language classes when they engaged in activities via Kahoot! in an organized and sustained manner. Teachers in this particular school also seemed to be using Kahoot! to assist in their language classes and ample support is given in terms of IT support and facilities. The expressed that the features of Kahoot! such as realtime based activities, competing with peers, allows them to track their progress and interactive nature were beneficial to their language learning.

Kahoot! allows teachers to be innovative and enhances students' learning engagement. Feedback can also be given instantly, thus students can monitor their own learning. Kahoot! based activities are relatively easy to design for teachers and offers students fun and 
interactive learning experiences. As the results of this study show, almost all the students found Kahoot! to be an effective learning experience and they feel happy and competitive when they are engaged in Kahoot! based activities. Teachers in this study also expressed positive experiences about the use of Kahoot! in their classes.

Kahoot! is a suitable platform to use for all levels of students, in most subjects and especially language classes. Students are normally eager to use their mobile phones or tablets and implement technology into the classroom. These applications provide a positive environment in the classroom, increase energy and add enjoyable moments in learning (Drigas \& Charami, 2014). Kahoot! is also able to motivate students and promote competitive as well as cooperative learning environments (Malamed, 2012). Kahoot! is also an effective assessment tool whereby all the results, scores and percentages of the questions can be recorded online and downloaded manually too. All level of students can benefit by getting involved in gamebased learning platforms like Kahoot!. The games created in the Kahoot! platform too can be kept for other classes and teachers can re-use and adapt the games for other classes in the future. Kahoot! provides positive learning experiences to students as shown in this study. Kahoot! is also a tool for teachers to engage their students in language classrooms.

\section{References}

Bicen, H. (2018). Perceptions of students for gamification approach: Kahoot! as a case study. International Journal of Emerging Technologies in Learning, 13(2).

Bitner, N. \& Bitner, J. (2002). Integrating technology into the classroom: Eight keys to success. Journal of Technology and Teacher Education, 10(1), 95-100. Norfolk, VA: Society for Information Technology \& Teacher Education. Retrieved January 15, 2019 from https://www.learntechlib.org/primary/p/9304/.

Bernard, J., Chang, T. W., Popescu, E., \& Graf, S. (2017). Learning style identifier: Improving the precision of learning style identification through computational intelligence algorithms. Expert Systems with Applications, 75, 94-108.

Bransford, J., Brown, A., \& Cocking, R. (2007). How people learn: Brain, mind, experience, and school. São Paulo: Senac Publisher.

Chun, D., Kern, R. \& Smith, B. (2016). Technology in language use, language teaching, and language learning. The Modern Language Journal, 100: 64-80. doi:10.1111/modl.12302.

Cox, R. and Rogers, J. (2005). Enter: The (well-designed) lecture. The Teaching Professor. 19(5), pp. 1-6.

Dellos, R. (2015). Kahoot! A digital game for learning. International Journal of Technology and Distance Learning. 12(4), 49 - 52.

Deterding, S., Dixon, D., Khaled, R., \& Nacke, L. (2011). From game design elements to gamefulness: defining gamification. In Proceedings of the 15th International Academic MindTrek Conference: Envisioning Future Media Environments (MindTrek '11). New York: ACM http://doi.acm.org/10.1145/2181037.2181040.

Drigas, A., \& Charami, F. (2014). ICTs in English Learning and Teaching. Open Research Online.2(4). doi: 10.3991/ijes.v2i4.4016.

Graham, K. (2015). TechMatters: Getting into Kahoot! (s): Exploring a game-based learning system to enhance student learning. LOEX Quarterly, 42(3), 6-7.

Retrieved from http://commons.emich.edu/loexquarterly/vol42/iss3/4.

Icard, S. B. (2014). Educational Technology best practices. International Journal of Instructional Technology and Distance Learning, 11(3), 37-41.

Kilickaya, F., \& Krajka, J. (2010). Teachers' technology use in vocabulary teaching. Academic Exchange Quarterly, 81-86. 
Kim, B., \& Reeves, T. C. (2007). Reframing research on learning with technology: In search of the meaning of cognitive tools. Instructional Science, 35(3), 207-256.

King, A. (2017). Using Kahoot!. Australian Mathematics Teacher, 73(4), 35-36.

Koile, K. and Singer, D.A. (2006). Improving learning in CS1 via tablet pc-based in-class assessment. In Proceedings of ICER 2006, September 9-10, 2006, University of Kent, Canterbury, UK.

Lee, J. \& Hammer, J. (2011). Gamification in education: What, how, why bother? Academic Exchange Quarterly, 15 (2).

Livingston, K. A. (2015). The impact of Web 2.0 in education and its potential for language learning and teaching. International Journal of Instructional Technology and Distance Learning, Vol 12(4), pp. 3 - 14.

Malamed, C. (2012). Book review: 'The gamification of learning and instruction: Gamebased methods and strategies for training and education' by Karl Kapp. Elearn, 2012(5), 3. http://dx.doi.org/10.1145/2207270.2211316.

Medina, E.G.L., \& Hurtado, C.P.R. (2017). Gamification in biology teaching: A sample of Kahoot! application. Turkish Online Journal of Qualitative Inquiry, 8(1), 396-414. Doi: 10.17569/tojqi.335956.

Medvedovska, D., Skarlupina, Y., \& Turchina, T. (2016). Integrating online educational applications in the classroom. European Humanities Studies, State and Society.

Meyer, K.A. (2010). Web 2.0 research: Introduction to the special issue. Internet and Higher Education 13, pp. 226 - 232.

Moersch, C. (1998) Enhancing students' thinking skills: Exploring model technologyIntegration sites. Learning \& Leading with Technology, 25(6), 50-53.

Nicol, D. J. \& Milligan, C. (2006), Rethinking technology-supported assessment in terms of the seven principles of good feedback practice. In C. Bryan and K. Clegg (Eds), Innovative Assessment in Higher Education, Taylor and Francis Group Ltd, London Page 1.

Piskorz, E.Z. (2017). Kahoot! it or not? Can games be motivating in learning grammar? Teaching English with Technology. 16(3), 17-36. Retrieved from: http://www.tewtjournal.org.

Saadé, R.G. (2003). Web-based educational information system for enhanced learning, EISEL: student assessment. Journal of Information Technology Education: Research, 2(1), 267-277. Informing Science Institute. Retrieved November 14, 2019 from https://www.learntechlib.org/p/111477/.

Yapici, U., \& Karakoyun, F. (2017). Gamification in Biology teaching: A sample of Kahoot! application. Turkish Online Journal of Qualitative Inquiry, 8(4), 396-414.doi: 10.17569/tojqi.335956.

Zhao, Y., Pugh, K., Sheldon, S. \& Byers, J.L. (2002). Conditions for classroom technology innovations. Teachers College Record, 104(3), 482-515. Retrieved January 15, 2019 from https://www.learntechlib.org/p/94690/. 